\title{
Nutritional survey of patients in a general surgical ward: is there an effective predictor of malnutrition?
}

\author{
W D NEITHERCUT,* A D S SMITH, ${ }^{*}$ J MCALliSTER,* G LA FERLA $\dagger$ \\ From the *Department of Pathological Biochemistry, Western. Infirmary and Gartnavel General Hospital, \\ Glasgow, and the †Department of Surgery, Gartnavel General Hospital, Glasgow
}

SUMMARY A survey of patients in a general surgical ward was undertaken to establish biochemical and anthropometric standards which could be used to detect malnourished patients in hospital. Results of biochemical and anthropometric tests of nutritional status were compared with assessment by a clinician and the quick nutritional index of Seltzer. ${ }^{1}$ Triceps skinfold thickness and serum albumin concentrations indicated that $29 \%$ and $35 \%$ of patients, respectively, were undernourished compared with $16 \%$ by clinical assessment and $17 \%$ by the quick nutritional index. Significant correlations $(p<0.001)$ between serum albumin and transferrin concentrations and arm muscle area were found for men but not for women. Poor nutritional specificity and sensitivity of some anthropometric and biochemical tests may account for the difference in the level of undernutrition found by these tests and clinical assessment. This shows the importance of the choice of test in influencing the level of undernutrition detected.

Anthropometric standards ${ }^{2-5}$ currently used in the assessment of nutritional status by measurement of height, weight, skin fold thickness, and mid-arm circumference have been taken from healthy populations in various parts of the world and may nutritionally misclassify ill and older European populations. ${ }^{67}$ Similarly, reference ranges for biochemical indices derived from young healthy people may be inappropriate for nutritional assessment of seriously ill patients ${ }^{8-10}$ because serum protein concentrations, which are often used to assess nutritional status, are influenced by water retention and losses, capillary permeability, the acute phase response, and losses into the gastrointestinal tract and urine. The level of undernutrition found in surgical inpatients has been estimated at between $50 \%$ (with a serum albumin concentration less than $35 \mathrm{~g} / \mathrm{l}^{11}$ ) and $16 \%$ (with a serum albumin concentration less than $30 \mathrm{~g} / \mathrm{l}^{12}$ ); reduced arm muscle circumference has been reported in between $48 \%{ }^{12}$ and $30 \%{ }^{13}$ of patients. We therefore undertook a nutritional survey of 157 consecutive surgical inpatients to establish values for biochemical and anthropometric nutritional indices in patients in a general surgical ward and to compare the level of undernutrition found by these indices with those found by an experienced clinician ${ }^{1415}$ and with the quick nutritional index. ${ }^{116}$

\section{Material and methods}

All inpatients, including both preoperative and postoperative patients, from one general surgical ward who were able to give informed consent were included in the survey, which lasted 10 weeks. Height was measured using a 2 metre wooden rule and body weight was measured on the ward scales. Mid-arm circumference was measured using a linen tape at the midpoint between the acromion and olecranon process on the non-dominant arm. Triceps skinfold thickness was measured in triplicate at the same level using Holtain calipers and the mean value calculated. All anthropometric measurements were performed by one observer. Arm muscle area, arm fat area, and body mass index were calculated using the following equations ${ }^{5}$ :

\footnotetext{
Arm muscle area $\left(\mathrm{cm}^{2}\right)=(\text { mid-arm circumference }(\mathrm{cm})-\pi \text { triceps skinfold thickness }(\mathrm{cm}))^{2} / 4 \pi$

Arm fat area $\left(\mathrm{cm}^{2}\right)=($ triceps skinfold thickness $(\mathrm{cm}) \times$ mid-arm circumference $(\mathrm{cm})) / 2-\pi(\text { triceps skinfold thickness }(\mathrm{cm}))^{2} / 4$ Body mass index $=$ Body weight $(\mathrm{kg}) /(\text { height }(\mathrm{cm}))^{2}$
} 
A blood sample was taken at the time of anthropometric assessment and centrifuged at $2000 \mathrm{~g}$ for 10 minutes at room temperature. The serum was analysed for albumin concentration by the bromocresol green method (SMAC I, Technicon Instruments Co, Basingstoke); prealbumin and transferrin concentrations by laser immunonephelometry (Hyland, Travenol, Thetford); and serum zinc concentrations by atomic absorption spectrophotometry (IL Video 11, Instrumentation Laboratories, Warrington). Lymphocyte counts were obtained from a Coulter counter S2 plus (Coulter Electronics, Luton).

The quick nutritional index indicated undernutrition if the serum albumin concentration was less than $35 \mathrm{~g} / 1$ and the lymphocyte count was less than $1.5 \times 10^{9} / 1^{1}{ }^{16}$

An experienced clinician independently examined each patient and awarded a nutritional score on a linear scale from 1 (cachectic) to 7 (obese). Patients who scored 1 or 2 were clinically malnourished, with the score reflecting the clinical impression of severity of malnutrition. At discharge the diagnosis, type of surgical procedure, and length of stay were recorded.

Statistical methods used were Student's $t$ test for comparison of means, $\chi^{2}$ test with Yates's correction, and product moment correlation coefficients. ${ }^{17}$

\section{Results}

\section{STUDY POPULATION (TABLES 1 AND 2)}

Seventy three men and 84 women with mean (SD) ages of 56 (18) years and 61 (19) years, respectively, were studied (difference not significant, $\chi^{2}$ test). A total of 104 patients had had operations, including 49 laparotomies. The mean (SD) duration of stay was 14.4 (17) days for both sexes. Twenty six (17\%) patients developed complications: these included eight deaths, 11 wound infections, four fistulae, and three deep vein thromboses.

\section{ANTHROPOMETRIC DATA (TABLE 3)}

Men under the age of 40 were significantly taller $(p<$ $0.01)$ and those over 70 had reduced arm muscle area $(\mathrm{p}<0.05)$, but otherwise there were no significant differences in weight, mid-arm circumference, triceps skinfold thickness, arm fat area, or body mass index. Women under the age of 40 were also taller $(\mathrm{p}<$ 0.02 ), and for both men and women under 40 hospital stay was significantly shorter $(\mathrm{p}<0.01)$ than for older age groups.

\section{LA BORATOR Y DATA (TABLE 4)}

Patients under the age of 40 had a higher mean serum albumin concentration than older patients $(p<0.01)$, ¿ and significant lymphopenia was found in men over 을 $70(\mathrm{p}<0.01)$. The mean serum zinc concentrations were below the reference range for all groups. No significant differences were found by $\chi^{2}$ test for serum protein concentrations before and after operation, but there was significant postoperative lymphopenia in patients over $70(p<0.01)$.

\section{PREVALENCE OF MALNUTRITION (TABLE 5)}

The clinician and the quick nutritional index classified $16 \%$ and $17 \%$ of patients, respectively, as undernourished. These percentages were compared with those found by the other methods using values proposed as discriminants of poor nutritional status for serum proteins, ${ }^{111218}$ for triceps skinfold thickness and arm muscle area, ${ }^{1418}$ and body mass index. ${ }^{19}$ Clearly, the cut off value chosen influences the numbers of patients identified. A serum albumin concentration of less than $30 \mathrm{~g} / \mathrm{l}$, together with a low body

Table 1 Surgical procedures

\begin{tabular}{llllll}
\hline & \multicolumn{3}{l}{ Surgical procedure } & & \\
\cline { 2 - 6 } & $\begin{array}{l}\text { Malignancy palliative } \\
\text { treatment only }\end{array}$ & Laparotomy & $\begin{array}{l}\text { Non-abdominal } \\
\text { surgery }\end{array}$ & Minar procedures & Trauma \\
\hline Men & 15 & 22 & 9 & 18 & 3 \\
Women & 10 & 27 & 9 & 16 & 2 \\
\hline
\end{tabular}

Table 2 Prevalence of malignant disease

\begin{tabular}{|c|c|c|c|c|c|c|}
\hline \multirow[b]{2}{*}{ Sex } & \multicolumn{6}{|l|}{ Disease category } \\
\hline & Non-malignant disease & $\begin{array}{l}\text { Carcinoma } \\
\text { of colon }\end{array}$ & $\begin{array}{l}\text { Carcinoma } \\
\text { of breast }\end{array}$ & $\begin{array}{l}\text { Carcinoma } \\
\text { of oesophagus }\end{array}$ & $\begin{array}{l}\text { Carcinoma } \\
\text { of stomach }\end{array}$ & $\begin{array}{l}\text { Other } \\
\text { malignant disease }\end{array}$ \\
\hline $\begin{array}{l}\text { Men } \\
\text { Women }\end{array}$ & $\begin{array}{l}56 \\
62\end{array}$ & $\begin{array}{r}7 \\
10\end{array}$ & $\begin{array}{l}0 \\
6\end{array}$ & $\begin{array}{l}2 \\
1\end{array}$ & $\begin{array}{l}6 \\
0\end{array}$ & $\begin{array}{l}2 \\
5\end{array}$ \\
\hline
\end{tabular}


Table 3 Anthropometric and clinical data by age and sex

\begin{tabular}{|c|c|c|c|c|c|c|c|c|c|c|}
\hline Sex & $\begin{array}{l}\text { Age group } \\
\text { (years) }\end{array}$ & $\begin{array}{l}\text { Height } \\
\text { (cm) }\end{array}$ & $\begin{array}{l}\text { Body } \\
\text { weight } \\
\text { (kg) }\end{array}$ & $\begin{array}{l}\text { Mid-arm } \\
\text { circumference } \\
\text { (cm) }\end{array}$ & $\begin{array}{l}\text { Triceps } \\
\text { skinfold } \\
\text { thickness }\end{array}$ & $\begin{array}{l}\text { Arm muscle } \\
\text { area }\left(\mathrm{cm}^{2}\right)\end{array}$ & $\begin{array}{l}\text { Arm fat } \\
\operatorname{area}\left(\mathrm{cm}^{2}\right)\end{array}$ & $\begin{array}{l}\text { Body mass } \\
\text { index }\end{array}$ & $\begin{array}{l}\text { Length of } \\
\text { hospital stay } \\
\text { (days) }\end{array}$ & $\begin{array}{l}\text { Median } \\
\text { clinical score }\end{array}$ \\
\hline \multirow[t]{3}{*}{ Men } & \multirow{3}{*}{$\begin{array}{l}16-39 \\
(n=16) \\
40-69 \\
(n=39) \\
70+ \\
(n=18)\end{array}$} & \multirow{2}{*}{$\begin{array}{l}175(7.4) \\
p<0.01 \\
168(8.2)\end{array}$} & $71 \cdot 2(11 \cdot 9)$ & $28 \cdot 2(3 \cdot 3)$ & $1 \cdot 28(0 \cdot 76)$ & $46 \cdot 3(9 \cdot 3)$ & $15.8(8.8)$ & $23 \cdot 1(3 \cdot 5)$ & $8 \cdot 8(6)$ & 4 \\
\hline & & & $70 \cdot 4(13 \cdot 5)$ & $27 \cdot 9(3 \cdot 8)$ & $1.34(0.74)$ & $44 \cdot 4(10 \cdot 8)$ & $16 \cdot 5(6)$ & $24.4(3.9)$ & $13(15)$ & 6 \\
\hline & & $166(7 \cdot 8)$ & $62.9(11.9)$ & $25 \cdot 4(3 \cdot 2)$ & $1 \cdot 1(0.56)$ & $\begin{array}{l}38.1(8.7) \\
p<0.05\end{array}$ & $12 \cdot 6(6 \cdot 4)$ & $22 \cdot 5(3 \cdot 5)$ & $22(23)$ & NA \\
\hline \multirow[t]{3}{*}{ Women } & \multirow{3}{*}{$\begin{array}{l}16-39 \\
(n=15) \\
40-69 \\
(n=37) \\
70+ \\
(n=32)\end{array}$} & \multirow{2}{*}{$\begin{array}{l}159(4 \cdot 5) \\
p<0.02 \\
157(7.2)\end{array}$} & $57 \cdot 2(10 \cdot 4)$ & $26 \cdot 3(3 \cdot 8)$ & $2 \cdot 15(0 \cdot 89)$ & $30 \cdot 2(4 \cdot 8)$ & $21 \cdot 6(9.9)$ & $22 \cdot 5(4 \cdot 1)$ & \multirow{2}{*}{$\begin{array}{l}8(3) \\
p<0.001 \\
13.6(14)\end{array}$} & 3 \\
\hline & & & $59 \cdot 4(15 \cdot 7)$ & $27 \cdot 4(5 \cdot 2)$ & $2 \cdot 18(1.03)$ & $33 \cdot 6(9 \cdot 5)$ & $23 \cdot 3(12 \cdot 3)$ & $23 \cdot 6(5 \cdot 5)$ & & 6 \\
\hline & & $\begin{array}{l}151(6.6) \\
p<0.01\end{array}$ & $52 \cdot 6(12 \cdot 1)$ & $25 \cdot 5(3 \cdot 6)$ & $1 \cdot 7(0.68)$ & $32 \cdot 3(6 \cdot 9)$ & $17 \cdot 7(8 \cdot 0)$ & $22 \cdot 6(4 \cdot 6)$ & $18 \cdot 4(23)$ & 3 \\
\hline
\end{tabular}

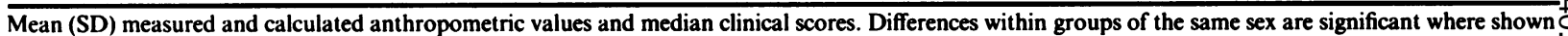
(Student's $t$ test).

$\mathrm{NA}=$ not applicable.

mass index and arm muscle area closely agreed with the quick nutritional index and clinician.

\section{CORRELATIONS BETWEEN BIOCHEMICAL AND}

ANTHROPOMETRIC DATA (TABLE 6)

Significant correlations were found between each pair of serum proteins $(p<0.001)$, the shorter half life proteins prealbumin and transferrin following changes in serum albumin concentration. Correlations between serum protein concentrations and arm muscle area were not significant in women, but for men these were significant $(p<0.001)$. Serum protein concentrations in men and women were not significantly different $\left(\chi^{2}\right.$ test). Albumin, but not prealbumin or transferrin, correlated significantly with length of stay $(p<0.001)$. Significant correlations for both sexes were found between triceps skinfold thickness and body mass index $(p<0.001)$, confirming previous reports that both are measures of body fat and may be used to detect calorie depletion. ${ }^{18}$

\section{Discussion}

The mean arm muscle areas found in this survey are lower than values derived from standard tables, ${ }^{2-514}$ but only $16 \%$ of patients were thought to be undernourished by the clinician. This suggests a need to establish local anthropometric reference ranges before using anthropometric tests to identify malnourished patients within an ill population. The level of undernutrition shown by serum albumin concentration varied from $33 \%$ to $15 \%$ depending on whether $35 \mathrm{~g} / 1$ or $30 \mathrm{~g} / \mathrm{l}$ was chosen as a lower limit. This compares poorly with the clinician's estimate that $16 \%$ of patients were undernourished and the quick nutritional index estimate of $17 \%$ The figure illustrates the poor cross identification of undernourished patients by different methods. Triceps skinfold thickness and serum albumin concentration, which are commonly used for nutritional assessment, are sensitive but non-specific indices of under-

Table 4 Laboratory data by age and sex

\begin{tabular}{|c|c|c|c|c|c|c|}
\hline $\operatorname{Sex}$ & Age group (yeans)) & Allowmin $(\mathrm{g} / \mathrm{l})$ & Transferrin $(\mathrm{g} / \mathrm{l})$ & Prealbumin (mg/l) & Zinc $(\mu \mathrm{mol} / \mathrm{l})$ & $\begin{array}{l}\text { Lymphocyte } \\
\text { count }\left(\times 10^{9} / l\right)\end{array}$ \\
\hline \multirow[t]{3}{*}{ Men } & \multirow{3}{*}{$\begin{array}{l}16-39 \\
(n=16) \\
40-69 \\
(n=37) \\
70+ \\
(n=18)\end{array}$} & \multirow{2}{*}{$\begin{array}{l}41(4.5) \\
p<0.01 \\
37(7)\end{array}$} & $2 \cdot 3 \cdot(-6)$ & $227(113)$ & $11 \cdot 6(2 \cdot 2)$ & $1.98(0.59)$ \\
\hline & & & $2 \cdot 4(0.8)$ & $246(127)$ & $11 \cdot 2(2)$ & $1.85(0.55)$ \\
\hline & & $34(6 \cdot 3)$ & $2 \cdot 3(0 \cdot 7)$ & $224(95)$ & $10 \cdot 2(2 \cdot 4)$ & $\begin{array}{l}1.40(0.42) \\
p<0.01\end{array}$ \\
\hline \multirow[t]{3}{*}{ Women } & \multirow{3}{*}{$\begin{array}{l}16-39 \\
(n=14) \\
40-69 \\
(n=35) \\
70+ \\
(n=32)\end{array}$} & \multirow{2}{*}{$\begin{array}{l}40(3.6) \\
\mathrm{p}<0.01 \\
36(6.5)\end{array}$} & $2 \cdot 8(0 \cdot 7)$ & $270(121)$ & $11.4(1.8)$ & $2 \cdot 13(0 \cdot 57)$ \\
\hline & & & $2 \cdot 4(0 \cdot 8)$ & $268(129)$ & $10 \cdot 7(2 \cdot 2)$ & $2 \cdot 16(1 \cdot 15)$ \\
\hline & & $36(5)$ & $2 \cdot 3(0 \cdot 6)$ & $259(110)$ & $9 \cdot 8(2 \cdot 7)$ & $1.58(1 \cdot 11)$ \\
\hline
\end{tabular}

Mean (SD) with differences from overall mean for each sex shown where significant (Student's $t$ test).

Reference ranges in our laboratory: albumin $35-50 \mathrm{~g} / \mathrm{l}$, transferrin $2 \cdot 0-4 \cdot 0 \mathrm{~g} / \mathrm{l}$, prealbumin $180-400 \mathrm{mg} / \mathrm{l}$, zinc $12-18 \mu \mathrm{mol} / \mathrm{l}$, lymphocyte $1.5-4.0 \times 10^{9} / 1$ 
Table 5 Effect of index used on the percentage of patients at risk

\begin{tabular}{ll}
\hline Index & $\begin{array}{l}\% \text { of } \\
\text { group abnormal }\end{array}$ \\
\hline Albumin: & 33 \\
$<35 \mathrm{~g} / 1$ & 20 \\
$<32 \mathrm{~g} / \mathrm{l}$ & 15 \\
$<30 \mathrm{~g} / 1$ & 31 \\
Transferrin $<2.0 \mathrm{~g} / 1$ & 28 \\
Prealbumin $<180 \mathrm{mg} / 1$ & 29 \\
Triceps skinfold thickness & \\
$<1 \cdot 0 \mathrm{~cm}$ (men) & \\
$1 \cdot 3 \mathrm{~cm}$ (women) & 20 \\
Body mass index $<20$ & 15 \\
Arm fat area & \\
$<7.6$ (men) & \\
$<10 \cdot 4$ (women) & 18 \\
Arm muscle area & \\
$\quad<33 \mathrm{~cm}^{2}$ (men) & \\
$\quad<25 \mathrm{~cm}^{2}$ (women) & 17 \\
Quick nutritional index & 16 \\
Clinical score 1 or 2 & \\
\hline
\end{tabular}

nutrition because of the wide normal range of triceps skinfold thickness and the low serum albumin concentrations found in nutritionally replete patients in hospital. ${ }^{20}$ Serum zinc concentrations in $68 \%$ of patients were below the reference range. Circadian variation of serum zinc concentration has been described, ${ }^{21}$ and this may account for the low values found because all samples were collected after 1400 hours. As biochemical and anthropometric tests of nutritional status using standard reference ranges may be oversensitive when applied to patients in hospital, the true level of malnutrition in our patients may have been only $16-17 \%$, as identified by the clinician. This level of malnutrition is substantially lower than that reported previously, ${ }^{1-132223}$ but may reflect a difference in the severity of illness in our patients.

We found significant correlations between arm muscle area and serum protein concentrations, but when correlations were calculated for each sex, the

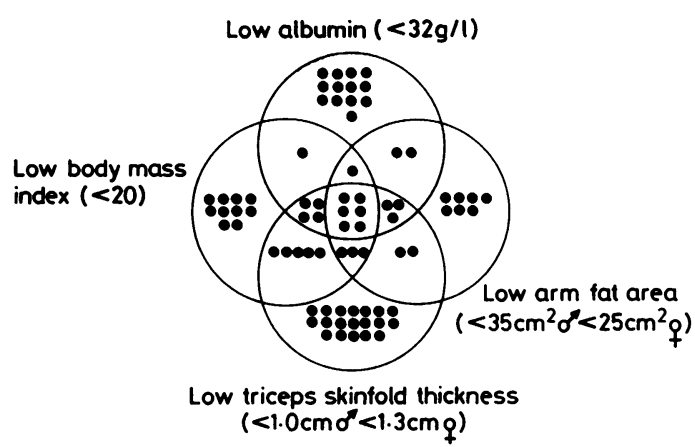

Overlap of reduced serum albumin, arm muscle area, triceps skinfold thickness, and body mass index with each dot representing one individual.

correlation was significant only for men. This sex difference has not been previously reported. Transfer- $\subseteq$ rin and prealbumin have been proposed as more sensitive markers of nutritional status than serum $\overrightarrow{0}$ albumin because they have shorter half lives. ${ }^{24-26} \infty$ Good correlations were found between all three protein concentrations $(p<0.001)$, but all overestimated the level of undernutrition when compared with the findings of the clinician or quick nutritional index. Mean serum albumin concentrations in patients under the age of 40 were, however, significantly higher than in the older age groups. This was not the case for prealbumin or transferrin and, with their greater responsiveness to nutritional repletion, either of these proteins may be more suitable for longitudinal nutritional assessment than albumin. ${ }^{1825}$ Clinical assessment of nutritional status is subjective, but objective identification of malnourished patients in hospital by anthropometric and biochemical tests is unreliable without evaluation of the effect of concurrent illness and age on these tests.

Table 6 Correlations between biochemical and anthropometric data

\begin{tabular}{|c|c|c|c|}
\hline Correlation & All patients & Men & Women \\
\hline Albumin $v$ prealbumin & 0.596 & 0.609 & \multirow{8}{*}{$\begin{array}{l}0.602 \\
0.720 \\
0.529 \\
0.237 \\
\mathrm{p}<0.05 \\
0.153 \\
\mathrm{NS} \\
0.126 \\
\mathrm{NS} \\
0.287 \\
\mathrm{p}<0.05 \\
0.687\end{array}$} \\
\hline Albumin $v$ transferrin & 0.683 & 0.654 & \\
\hline Transferrin $v$ prealbumin & 0.602 & 0.681 & \\
\hline Albumin $v$ arm muscle area & $0 \cdot 396$ & 0.614 & \\
\hline Prealbumin $v$ arm muscle area & $\begin{array}{c}0.219 \\
p<0.05\end{array}$ & 0.482 & \\
\hline Transferrin $v$ arm muscle area & 0.282 & 0.547 & \\
\hline Albumin $v$ no of days in hospital & -0.496 & $-0 \cdot 496$ & \\
\hline Body mass index $v$ triceps skinfold thickness & $0 \cdot 588$ & 0.670 & \\
\hline
\end{tabular}

NS = indicates not significant.

All values significant to $\mathrm{p}<0.001$ unless stated. 


\section{References}

1 Seltzer HM, Bastidas JA, Cooper DM, et al. Instant nutritional assessment. JPEN 1979;3:157-9.

2 Jeliffe DB. The assessment of nutritional status of the community with special reference to field surveys in developing regions of the world. WHO Monographs WHO Geneva, 1966.

3 Burr ML, Phillips KM. Anthropometric norms in the elderly. $\mathrm{Br}$ J Nutr 1984;51:165-9.

4 Frisancho AR. New norms for upper limbs fat and muscle areas for assessment of nutritional status. Am J Clin Nutr 1981:34:2540-5.

5 Rudman D, Bleier JC. Assessment of nutritional status. In: Petersdorf RG, ed. Harrisson's textbook of medicine. New York: McGraw-Hill, 1983.

$6 \mathrm{Klemm} \mathrm{JR}$, Allcock J. The distribution of supposed indicators of nutritional status in elderly patients. Age Ageing 1984;13:21-8.

7 Morgan DB, Newton HMV, Schorath CJ, et al. Abnormal indices of nutrition in the elderly a study of different clinical groups. Age Ageing 1986;15:65-75.

8 Friedman PJ, Campbell AJ, Caradoc-Davies TH. Hypoalbuminaemia in the elderly is due to disease not malnutrition. $J$ Clin Exp Gerontology 1985;7:191-204.

9 Varley H, Gowenlock AH, Bell M. Practical clinical biochemistry. London: Heinemann, 1980:331-43.

10 McPherson K, Healey MJR, Flynn FV, Piper KAJ. The effect of age, sex and other factors on blood chemistry in health. Clin Chim Acta 1975;84:373-97.

11 Bistrian BR, Blackburn GL, Hallowell E, Heddle R. Protein status of general surgical inpatients. JAMA 1974;230:858-60.

12 Hill GL, Blackett RL, Pickford I, et al. Malnutrition in surgical patients an unrecognised problem. Lancet 1977;i:689-92.

13 Mullen JL, Gertner MH, Busby GP. Implications of malnutrition in surgical patients. Arch Surg 1979;114:121-5.

14 Grant JP, Custer PB, Thurlow J. Current techniques of nutri- tional assessment. Surg Clin North Am 1981;61:437-63.

15 Baker JP, Detsky AS, Wessan DE, et al. Nutritional assessment: A comparison of clinical judgement and objective measurements. $N$ Engl J Med 1982;306:969-72.

16 Roy LB, Edwards PA, Barr LH. The value of nutritional assessment in the surgical patient. JPEN 1985;9:170-2.

17 Swinscow TDV. Statistics at square one. London: Mendip Press, 1978.

18 Haider M, Haider SQ. Assessment of protein-calorie malnutrition. Clin Chem 1984;30:1286-99

19 Dugdale AE. Family anthropometry: a new strategy for determining community nutrition. Lancet 1985; ;:672-3.

20 McLaren DS, Meguid MM. Nutritional assessment at the cross roads. JPEN 1983;7:575-9.

21 Morrisson B, Shenkin A, McClelland A, Robertson DA, et al. Intra individual variation in commonly analysed serum constituents. Clin Chem 1979;25:1799-805

22 Klidjian AM, Archer TJ, Foster DM, Karron SJ. Detection of dangerous malnutrition. JPEN 1982;6:199-21.

23 Klidjian AM, Foster KJ, Kammerling RM, et al. Relation of anthropometric and dynametric variables to serious post operative complications. Br Med J 1980;281:899-901.

24 Tuten MB, Wogt S, Dasse F, Leider Z. Utilisation of prealbumin as a nutritional parameter. JPEN 1985;9:709-11.

25 Sachs E, Bernstein LH. Protein markers of nutrition as related to sex and age. Clin Chem 1986;32:339-41.

26 Ingenbleek Y, Van Der Schriek HG, De Nayer P, De Visscher M. Albumin, transferrin and thyroxine binding prealbumin/ retinol binding protein (TBPA-RBP) complex in assessment of malnutrition. Clin Chem Acta 1975;63:61-7.

Requests for reprints to: Dr WD Neithercut, Department of Pathological Biochemistry, Western Infirmary, Glasgow G11 6NT, Scotland. 